\title{
SYNTHESIS OF ENCAPSULATED CHROMOLAENA ODORATA LEAF EXTRACT IN CHITOSAN NANOPARTICLE BY USING IONIC GELATION METHOD AND ITS ANTIOXIDANT ACTIVITY
}

\author{
KENI IDACAHYATI, WINDA TRISNA WULANDARI*, FIRMAN GUSTAMAN AND INDRA INDRA
}

Pharmacy Department, STIKes Bakti Tunas Husada, Jl. Cilolohan 36 Tasikmalaya, West Java, Indonesia

*Email: windatrisna@stikes-bth.ac.id

Received: 08 Aug 2021, Revised and Accepted: 15 Aug 2021

\begin{abstract}
Objective: The aim of this study was to determine the antioxidant activity of Chromolaena odorata.
\end{abstract}

Methods: Encapsulation of Chromolaena odorata leaf extract by nano chitosan was synthesized by using chitosan and NaTPP as the crosslinking agent. The antioxidant activity was conducted by using the DPPH method.

Results: Nanoparticles of Chromolaena odorata leaf extract has an average diameter of $675 \pm 218 \mathrm{~nm}$ and $+23.4 \pm 7.14 \mathrm{mV}$ of zeta potential. The antioxidant activity of its extract was $0.86 \mathrm{ppm}$, while its nanoparticle has the better antioxidant activity of $0.21 \mathrm{ppm}$.

Conclusion: Nanoparticles of Chromolaena odorata have very strong antioxidant activity and the potential to be external antioxidants.

Keywords: Nanoparticle, Plant extract, Chromolaena odorata, Antioxidant activity

(C) 2021 The Authors. Published by Innovare Academic Sciences Pvt Ltd. Thisis an open access article under the CC BYlicense (https://creativecommons.org/licenses/by/4.0/) DOI: https://dx.doi.org/10.22159/ijap.2021.v13s4.43828 Journal homepage: https://innovareacademics.in/journals/index.php/ijap

\section{INTRODUCTION}

Degenerative diseases are associated with aging that affects the function and structure of organs or tissues [1]. Degenerative diseases occur when cells and tissues lose their optimal function. The presence of chronic inflammation is one of the causes of degenerative diseases [2]. Diabetes mellitus, cardiovascular disease, cancer, Parkinson's and Alzheimer's are degenerative diseases which are health problems in the world [3]. Oxidative stress is one of the causes of degenerative diseases due to DNA damage [4]. Oxidative stress occurs when there is an imbalance between reactive oxygen species and antioxidants [1].

Chromolaena odorata is a plant pest because it is a competitor of the surrounding plants in absorbing water and nutrients. However, on the other hand, this plant also has various potential benefits for human life, in agriculture, it can be used as organic fertilizer, biopesticides and herbicides. In the medical field, traditionally, it can be used as medicine for wounds, diabetes, coughing and stopping bleeding [5].

Nanoparticles are colloidal particles that can act as drug delivery according to the desired target. In its manufacturing process, widely used polymers are derived from natural sources, synthetic or semisynthetic, which can be biodegradable or not [6]. Chitosan is a natural polysaccharide derived from chitin (which is in crustaceans) through the process of deacetylation. Chitosan use has increased rapidly over the past few years, especially in the pharmaceutical and food fields. This is due to low production costs, biodegradability and biocompatibility $[7,8]$.

The technique that can be used to increase the biological activity of compounds is by encapsulating in nanometric sizes [7]. Previous studies have shown that curcumin diethyl disuccinate encapsulated by chitosan-tripolyphosphate nanoparticles has better antioxidant activity when compared to without encapsulation [9]. As well as clove essential oil [CEO] encapsulated in chitosan nanoparticles by using the emulsion-ionic gelation method has higher antioxidant activity than free CEO [10]. The same results also on Catechin Hydrate $[\mathrm{CH}]$ nanoparticles which have better antioxidant activity [67.01 $\pm 0.15 \%]$ when compared to pure $\mathrm{CH}[65.69 \pm 0.34 \%]$ [11]. There was no one has reported the antioxidant activity of Chromolaena odorata loaded chitosan nanoparticles even though empirically, it has been widely used for treatment.

\section{MATERIALS AND METHODS}

\section{Materials}

The materials used is Chromolaena odorata leaf from Tasikmalaya, Indonesia. The other are ethanol 96\% (Bratachem $®$ ), Chitosan (Bratachem $®$ from shrimp, Deacetylation Degree of 99\%), NaTPP (Bratachem $\AA$ ), vitamin C (Bratachem $\AA$ ), 1,1-diphenyl-2picrylhidrazyl (DPPH) (Sigma Aldrich@), deionized water.

\section{Methods}

\section{Extraction of Chromolaena odorata leaf}

Chromolaena odorata leaf was extracted with 96\% ethanol solvent using maceration method for $3 \mathrm{~d}$ while shaken occasionally, then extract was filtered. The result was collected and concentrated with a rotary evaporator at $60^{\circ} \mathrm{C}$ to obtain a concentrated extract.

Phytochemical screening of Chromolaena odorata leaf

\section{Flavonoids}

Simplicia powder was inserted into a test tube that has been filled with water. Then it was heated and filtered. The obtained filtrate was added magnesium and alcohol with hydrochloric acid by comparison 1:1. Mixture was shaken for $5 \mathrm{~min}$. The formation of red, yellow or orange filtrate that can be pulled by amyl alcohol indicates the presence of flavonoids [12].

\section{Tannins-polyphenols}

Simplicia powder was put into a test tube that has been filled with water, it was heated, then filtered. Filtrate was divided into two parts. Solution of iron (III) chloride was added into the first part, the formation of blue-black color indicates the presence of tannins and polyphenols. Gelatin $1 \%$ was added into the second part; the formation of white sediment indicates the presence of tannins [12].

\section{Saponin}

Simplicia powder was extracted using water; then, it was heated and filtered. The obtained filtrate was cooled, then it was shaken firmly for a few minutes. The diluted hydrochloric acid added the formation of foam as high as $1 \mathrm{~cm}$ indicates presence of saponin compounds [12].

\section{Steroids}

Ether was added to the simplicia powder, then evaporated. After that, Liebermann-Burchad's reagents were dropped on residues, 
purple color formation indicates the presence of steroidtriterpenoids [12].

\section{Monoterpenoid-sesquiterpenoid}

Simplicia powder was extracted using ether and then it was evaporated. Vanillin- $\mathrm{H}_{2} \mathrm{SO}_{4}$ or sulfate reagents were added to the residue. The presence of monoterpenoid and sesquiterpenoid compounds is indicated by the formation of color [12].

\section{Synthesis of Chromolaena odorata nanoparticle}

Nanoparticle of Chromolaena odorata was synthesized by using an ionic gelation method. $10 \mathrm{mg}$ of extract produced was mixed with $3.5 \mathrm{ml}$ of $0.05 \%$ chitosan. The mixture was homogenized at a speed of $1000 \mathrm{rpm}$ for $24 \mathrm{~h}$ in a room temperature. After being homogeneous, $0.01 \%$ of NaTPP was added as much as $3.5 \mathrm{ml}$ drop by drop then stirred again for $3 \mathrm{~h}$. The nanoparticle produced was characterized by Particle Size Analyzer [PSA] to determine the particle size distribution and zeta potential to determine its stability [13].

\section{DPPH radical scavenging assay}

Antioxidant activity of extract and nanoparticle was determined by using the DPPH method. Test solution was mixed with DPPH at a ratio of 1:1 [volume]. It was incubated at room temperature in a dark place for $30 \mathrm{~min}$. Then, it was measured for its absorbance at a wavelength of $517 \mathrm{~nm}$ using the UV-Vis spectrophotometer. The percentage of antioxidant activity was calculated by following:

$$
\text { Inhibition [\%] }=\frac{\text { Absorbance of blank-Absorbance of sample }}{\text { Absorbance of Blank }} \times 100 \% \ldots . . . .[1]
$$

$\mathrm{IC}_{50}$ [Minimal concentration that can inhibit $50 \%$ of free radical] values can be calculated using a linear regression analysis from the graph [14].
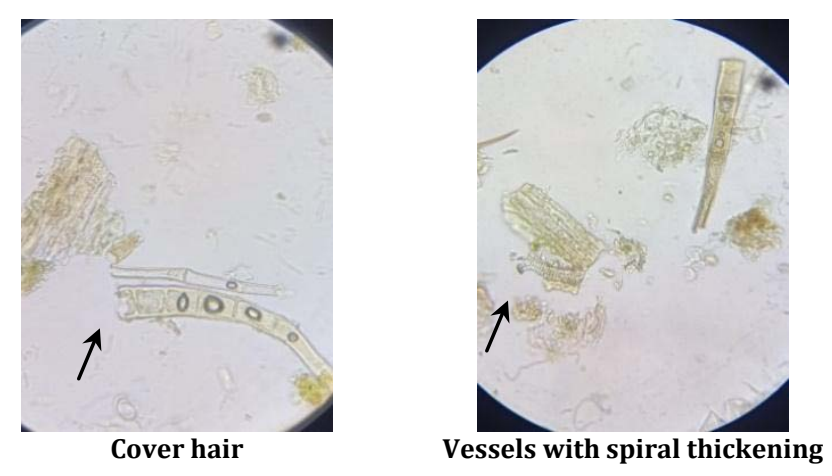

Fig. 1: Analysis of microscopic Chromolaena odgrata leaf

The extraction method used was the maceration method using 96\% of ethanol as solvent. The result of the maceration process obtained liquid

\section{RESULTS}

Phytochemical screening of Chromolaena odorata leaf extract

Phytochemical screening aims to find out what group of compounds are found in Chromolaena odorata simplicia and extract. The result of phytochemical screening can be seen in table 1 .

Table 1: Phytochemical screening of Chromolaena odorata leaf simplicia and extract

\begin{tabular}{lll}
\hline Phytochemical & Simplicia & Extract \\
\hline Flavonoids & + & + \\
Polyphenols & + & + \\
Tannins & - & - \\
Saponin & - & - \\
Steroids & + & - \\
Seskuiterpenoid & + & + \\
Monoterpenoid & + & + \\
Quinone & + & + \\
\hline
\end{tabular}

The results in table 1 shows that both simplicia and extract contain flavonoids, polyphenols, and seskuiterpenoid, monoterpenoid and quinone compounds. Steroids exist on simplicia but they are not found on extracts. Macroscopic and microscopic analysis of Chromolaena odorata Leaf are shown in table 2 and fig. 1.

Table 2: Analysis macroscopic of Chromolaena odorata leaf extract

\begin{tabular}{ll}
\hline Characteristics & Extract \\
\hline Color & Dark Green \\
Odor & Distinctive Smell \\
Taste & Bitter \\
Shape & Thick \\
\hline
\end{tabular}

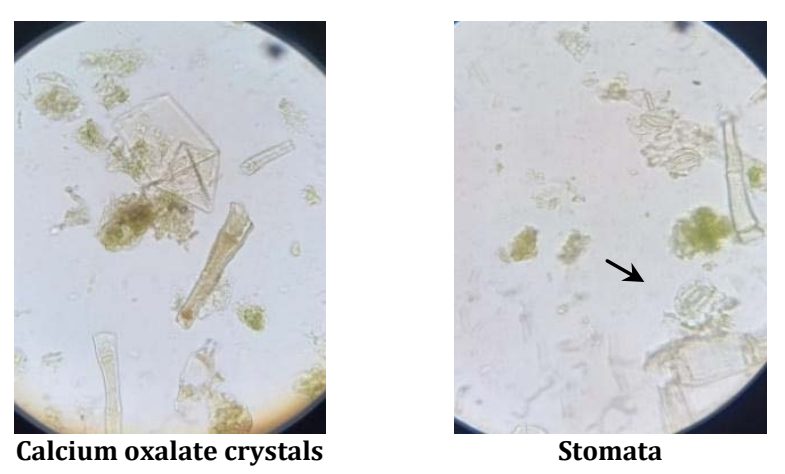

Table 3: The results of Chromolaena odorata leaf extraction

\begin{tabular}{lll}
\hline Chromolaena odorata leaf powder & Concentrated extract & Result (\%) \\
\hline $900 \mathrm{~g}$ & $65.33 \mathrm{~g}$ & $7.26 \% \mathrm{w} / \mathrm{v}$ \\
\hline
\end{tabular}

\section{Characterization of Chromolaena odorata leaf extract loaded} chitosan nanoparticle

\section{Particle size analysis and zeta potential}

Encapsulated Chromolaena odorata in Chitosan Nanoparticle [ECC] were prepared by using an ionic gelation method with NaTPP as a crosslinker. Distribution of particle size and zeta potential can be seen in fig. 2 and fig. 3 respectively. Particle analysis shows that the average diameter was $675.1 \pm 218 \mathrm{~nm}$. Nanoparticles produced has a zeta potential value of $+23.4 \pm 7.14 \mathrm{mV}$. extract, which is evaporated to obtain concentrated extract. The result obtained from this maceration process was $7.26 \%$ as seen in table 3 .
Antioxidant activity of Chromolaena odorata leaf extract loaded chitosan nanoparticle

The ability of nanoparticles to act as free radical scavengers was measured by the DPPH method. This method is widely used to observe the antioxidant activity. Extract of Chromolaena odorata Leaf (EC), Encapsulated Chromolaena odorata in Chitosan Nanoparticle (ECC) and vitamin C, as a comparison, have been measured for their antioxidant activity. The results can be seen in table 4 


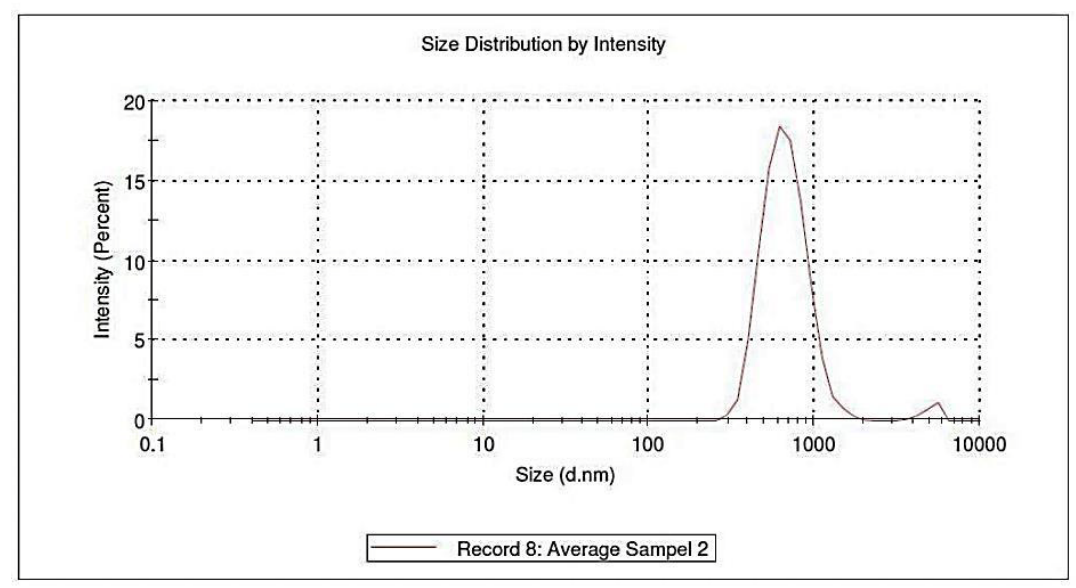

Fig. 2: Particle size analysis of nanoparticles

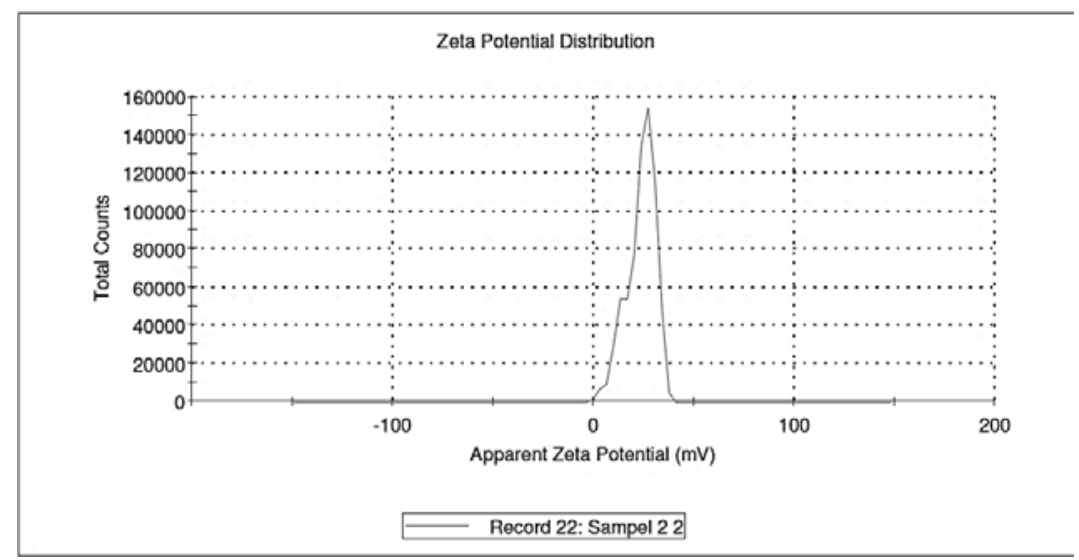

Fig. 3: Zeta potential analysis of nanoparticles

Table 4: $\mathrm{IC}_{50}$ value of EC, ECC and vitamin C

\begin{tabular}{lll}
\hline IC $_{50}[$ ppm] & & \\
\hline EC & ECC & Vitamin C \\
\hline 0.86 & 0.21 & 0.14 \\
\hline
\end{tabular}

\section{DISCUSSION}

The maceration method was chosen because it uses simple tools and processes, $96 \%$ of ethanol solvent is used because the target compound is a flavonoid that is soluble in ethanol. Flavonoids and polyphenols are compounds contained in Chromolaena odorata leaf that can provide antioxidant activity. Flavonoids have the ability to reduce free radicals and act as antioxidants. The mechanism of flavonoids as antioxidants is by donating hydrogen ions so that they can neutralize the toxic effects of free radicals. Phenolic compounds also have antioxidant activity because they can reduce free radicals by donating electrons through the hydrogen atoms of the hydroxyl group [15]. Steroids compounds are not found in extract but they do exist in simplicia. It indicates that the steroid is not attracted by ethanol solvents at the time of the maceration process. Ionic gelation is the easiest technique to produce nanoparticles. This technique is made through electrostatic interaction between cationic amino groups in chitosan with anions from tripolyphosphate [16] Suspension is called nanoparticles when it has size of $10-1000 \mathrm{~nm}$ [17], so the extracts produced are already in the nanometer range. The nanoparticle has a polydispersity index of 0.380 , indicating a homogenous dispersion because the value is between 0 to 1 [17].

Besides the determination of particle size, the measurement of potential zeta value is very important in producing nanoparticles. Zeta potential value shows the stability of nanoparticles, it is said to be stable if the value is lesser than- $30 \mathrm{mV}$ and more than $+30 \mathrm{mV}$ [18]., so it is still possible to become aggregates.

It was observed that the $\mathrm{IC}_{50}$ value of ECC is lower than EC, which means that its antioxidant activity is stronger and close to vitamin $\mathrm{C}$. Flavonoid compounds contained in EC, as shown in the results of phytochemical screening, encapsulated by chitosan nanoparticle have shown enhanced antioxidant activity $[11,19]$.

This result was consistent with the research of Karimirad et al. stated that encapsulation of essential oil by chitosan nanoparticles can extend shelf life and there are more antioxidant enzymes than controls [7]. The increased antioxidant activity is also caused by chitosan which has hydroxyl and amine groups which can prevent free radical chain reactions $[13,20,21]$.

Nanoparticle of Parkia speciosa leaves extract has IC $_{50}$ value of 15.26 ppm [22], nanoparticle of Garcinia mangostana L. leaves extract has IC $_{50}$ of $0.81 \mathrm{ppm}$ [18] and nanoparticle of Annona Muricata L has bigger IC $_{50}$ value, it was $46.88 \mathrm{ppm}$ [17]. It means that nanoparticles of Chromolaena odorata leaves extract have better antioxidant activity when compared to the results of other previous studies.

\section{CONCLUSION}

Chromolaena odorata leaf extract encapsulated by nanochitosan has been successfully synthesized by using ionic gelation method. It has 
an average diameter of $675 \pm 218 \mathrm{~nm}$ and $+23.4 \pm 7.14 \mathrm{mV}$ of zeta potential. Antioxidant activity of its extract is $0.86 \mathrm{ppm}$ while its nanoparticle has the better antioxidant activity of $0.21 \mathrm{ppm}$.

\section{FUNDING}

Nil

\section{AUTHORS CONTRIBUTIONS}

All the authors contributed equally.

\section{CONFLICT OF INTERESTS}

Declared none

\section{REFERENCES}

1. Sahardi NFNM, Ginger MS. (Zingiber officinale Roscoe) in the prevention of ageing and degenerative diseases: review of current evidence. Evid Based Complement Alternat Med. 2019 Aug 20. doi: 10.1155/2019/5054395

2. Mikirova NA, Kesari S, Ichim TE, Riordan NH. Effect of inflakine supplementation on the gene expression of inflammatory markers in peripheral mononuclear cells and on C-reactive protein in blood. J Transl Med. 2017;15(1):213. doi: 10.1186/s12967-017-1315-4, PMID 29058588.

3. Stambler I. Recognizing degenerative aging as a treatable medical condition: methodology and policy. Aging Dis. 2017;8(5):583-9. doi: 10.14336/AD.2017.0130, PMID 28966803.

4. Saez GT. DNA damage and repair in degenerative diseases 2016. Int J Mol Sci. 2017;18(1). doi: 10.3390/ijms18010166, PMID 28275213.

5. Saputra A, Gani A, Erlidawati E. Antioxidant activity of Siam gulma [Chromoleana odorata L]. Using 1,1-Diphenyl-2-Picrylhydrazil method. J IPA Pembelajaran. IPA. 2017;1(2):131-42.

6. Sur S, Rathore A, Dave V, Reddy KR, Chouhan RS, Sadhu V. Recent developments in functionalized polymer nanoparticles for efficient drug delivery system. Nano Struct Nano-Objects. 2019;20. doi: 10.1016/j.nanoso.2019.100397, PMID 100397.

7. Karimirad R, Behnamian M, Dezhsetan S. Bitter orange oil incorporated into chitosan nanoparticles: preparation, characterization and their potential application on antioxidant and antimicrobial characteristics of a white button mushroom. Food Hydrocoll. 2020;100. doi: 10.1016/j.foodhyd.2019.105387, PMID 105387.

8. Shetta A, Kegere J, Mamdouh W. Comparative study of encapsulated peppermint and green tea essential oils in chitosan nanoparticles: Encapsulation, thermal stability, in vitro release, antioxidant and antibacterial activities. Int J Biol Macromol. 2019;126:731-42. doi: 10.1016/j.ijbiomac.2018.12.161, PMID 30593811.

9. Sorasitthiyanukarn FN, Muangnoi C, Thaweesest W, Rojsitthisak P, Rojsitthisak P. Enhanced cytotoxic, antioxidant and antiinflammatory activities of curcumin diethyl disuccinate using chitosan-tripolyphosphate nanoparticles. J Drug Deliv Sci Technol. 2019;53. doi: 10.1016/j.jddst.2019.06.015, PMID 101118.
10. Hadidi M, Pouramin S, Adinepour F, Haghani S, Jafari SM. Chitosan nanoparticles loaded with clove essential oil: characterization, antioxidant and antibacterial activities. Carbohydr Polym. 2020 Feb;236:116075. doi: 10.1016/j.carbpol.2020.116075.

11. Kaur R, Rajput R, Nag P, Kumar S, Rachana M, Singh M. Synthesis, characterization and evaluation of antioxidant properties of catechin hydrate nanoparticles. J Drug Deliv Sci Technol. 2017;39:398-407. doi: 10.1016/j.jddst.2017.04.030.

12. Idacahyati K, Nurdianti L, Husni SS, Gustaman F, Wulandari WT. Nephroprotective activity of ethanol extract of kirinyuh (Chromolaena odorata l) in gentamicin induced nephrotoxicity in Wistar rats. Int J Appl Pharm. 2021;13;Special Issue 3:53-6.

13. Wulandari WT, Puspitasari R, Aprilia AY. Antioxidant activity of chitosan from the waste of green mussels shell (Perna viridis L.). Adv Health Sci Res 2020;26:33-5.

14. Poojary MM, Vishnumurthy KA, Vasudeva Adhikari A. Extraction, characterization and biological studies of phytochemicals from Mammea suriga. J Pharm Anal. 2015;5(3):182-9. doi: 10.1016/j.jpha.2015.01.002, PMID 29403930.

15. Maher $\mathrm{P}$. The potential of flavonoids for the treatment of neurodegenerative diseases. Int J Mol Sci. 2019;20(12). doi: 10.3390/ijms20123056, PMID 31234550.

16. Rizkita LD, Ysrafil MR, Astuti I. Chitosan nanoparticles mediated delivery of MIR-106B-5P to breast cancer cell lines MCF-7 and T47D. Int J Appl Pharm. 2021;13(1):129-34.

17. Desmiaty Y, Rahmat D, Afifah H. Preparation of nanoparticles containing soursop (Annona muricata L.) leaves extract using gelation ionic method and determination of its antioxidant activity. J Pharmaeutical Biol Chem Sci. 2016;2017;275:275-9.

18. Diniatik KA, Siswanto A, Imtihan ZF, Wahyudi A. Formulation of nanoparticles of ethanol extract of Garcinia mangostana 1. Leaves as an antioxidant with pectin as cross-linker and chitosan variation as polymer. Int J Recent Technol Eng. 2019;8;2 Special Issue 9:779-83.

19. Nallamuthu I, Devi A, Khanum F. Chlorogenic acid loaded chitosan nanoparticles with sustained release property, retained antioxidant activity and enhanced bioavailability. Asian J Pharm Sci. 2015;10(3):203-11. doi: 10.1016/j.ajps.2014.09.005.

20. Qin Y, Liu Y, Yuan L, Yong H, Liu J. Preparation and characterization of antioxidant, antimicrobial and $\mathrm{pH}$-sensitive films based on chitosan, silver nanoparticles and purple corn extract. Food Hydrocoll. 2019;96(April):102-11. doi: 10.1016/j.foodhyd.2019.05.017.

21. Li Y, Ying Y, Zhou Y, Ge Y, Yuan C, Wu C, Hu Y. A pH-indicating intelligent packaging composed of chitosan-purple potato extractions strength by surface-deacetylated chitin nanofibers. Int J Biol Macromol. 2019;127:376-84. doi: 10.1016/j.ijbiomac.2019.01.060, PMID 30658144.

22. Ravichandran V, Vasanthi S, Shalini S, Shah SAA, Tripathy M, Paliwal N. Green synthesis, characterization, the antibacterial, the antioxidant and photocatalytic activity of Parkia speciosa leaves extract mediated silver nanoparticles. Results Phys. 2019;15. doi: 10.1016/j.rinp.2019.102565, PMID 102565. 